WORKING PAPER

\title{
Developing and applying the Mission-oriented Innovation Systems (MIS) approach
}

\author{
Wesseling, J.H. ${ }^{1}$; Meijerhof, N. $^{2}$ \\ ${ }^{1}$ Utrecht University; ${ }^{2}$ PNO Consultants and RVO
}

\begin{abstract}
:
Building on the literature on Mission-oriented Innovation Policy, governance, transition studies and innovation systems, this paper develops an initial approach to studying the Mission-oriented Innovation System (MIS). Central to the MIS is the concept of a mission arena, in which actors formulate and govern the mission as well as mobilize and direct other, existing system components, in order to legitimize, develop, diffuse and adopt innovative mission solutions. The MIS approach involves a problem-solutions diagnosis and an analysis of structural, functional, and systemic barriers. To provide formative mission governance recommendations, the systemic barriers are contrasted with the mission governance actions that the arena undertakes to mobilize the MIS. A case study of the Dutch mission for sustainable shipping illustrates the value of the MIS approach.
\end{abstract}

\section{Highlights:}

- The structural-functional approach can be extended from Technological Innovation Systems to studying MIS

- An MIS approach should address the wickedness, temporality, embeddedness and transformative directionality of missions

- Distinguishing a mission arena within an overall MIS helps account for these mission qualities in studying and assessing MIS governance

- The MIS approach can be used for formative or summative evaluation of mission governance actions

\section{Keywords:}

mission-oriented innovation policy; mission arena; mission governance; evaluation; social innovation; technological innovation system 


\section{Introduction}

Scholars from various backgrounds, including transition and innovation systems literatures and government-led development and mainstream economics literatures, have signaled the arrival of a 'third generation' innovation policy, aimed at overcoming societal challenges (Haddad et al., 2019). The first literature stream labels this third generation as 'transformative innovation policy' (Diercks et al., 2019; Grillitsch et al., 2019; Schot \& Steinmueller, 2018), whereas the second describes it as 'challenge-led, Mission-oriented Innovation Policy' (MIP) (Foray et al., 2012; Kattel \& Mazzucato, 2018; Robinson \& Mazzucato, 2019). These previously separate literature streams have converged around a notion of societal challenge-led innovation policy that underlines (a) the wickedness of societal problems; (b) the importance of directionality provided by governance constellations across sectors, disciplines and geographical levels, which involve a plurality of stakeholders and which balance the short and long term; (c) the multifaceted nature of innovation policy (or policy mixes) that requires new rationalities; and (d) the need for behavioral or social change in addition to technological fixes (Haddad et al., 2019, pp. 12-13).

This generation of MIP has rapidly gained interest in the policy arena at different levels of government and governance, although implementation follows at a slower pace (Janssen et al., 2020). It is different from transformative innovation policy in that it is more explicitly focused on providing directionality through ambitious, actionable, measurable, and time-bound goals (Haddad et al., 2019; Wanzenböck et al., 2020). Furthermore, missions require socio-technical transformation - the replacement of harmful goods and practices by innovative solutions - but the 'radicality' of that transformation depends on the mission ${ }^{1}$ (Janssen et al., 2021). Transformative missions also require substantial governance and the involvement of stakeholders other than only the government (Larrue, 2021). In this paper, we therefore refer to measures that aim to achieve a mission goal as 'mission governance actions' rather than as MIP.

Although promising, missions remain understudied in practice, and a deeper understanding is needed of the innovation dynamics produced by missions and supportive governance actions, so that more effective policy and governance interventions can be designed (Janssen et al., 2021). Systems perspectives are valuable in achieving this comprehensive level of understanding, but various authors argue that none of the current innovation systems and transition frameworks are sufficiently equipped to understand and systematically assess the impact of missions (Ghazinoory et al., 2020; Haddad \& Bergek, 2020; Hekkert et al., 2020). This is why Hekkert et al. (2020) call for a new perspective, the Mission-oriented Innovation System (MIS).

However, there are various challenges facing an MIS framework. First, and contrary to established innovation systems frameworks, MISs should not only include technologically innovative solutions, but also socially innovative solutions; after all, wicked societal problems such as climate change cannot be resolved by technological fixes alone (IPCC, 2018; Levin et al., 2012). Social innovations are described as "novel combinations of ideas and distinct forms of collaboration that transcend established institutional contexts" (Rehfeld et al., 2015, p. 1) and include the sharing economy, slow food, and sustainable consumption (Pel et al., 2020a). Innovation Systems centered around technological innovation perspectives emphasize change in the technological structural component as the output of the innovation system, arguing that it requires supportive changes in the other structural components of the innovation system, namely the actors, network and institutions (Bergek et al., 2015; Malerba et al., 2000). In contrast, Social Innovation Ecosystems turn this around and

\footnotetext{
${ }^{1}$ In practice, some practitioners also apply the mission label to non-transformative and technology-oriented 'accelerator' missions (Larrue, 2021; Wittmann et al., 2019), leading to conceptual diffuseness. We instead follow Janssen et al.'s (2021) narrower mission definition of transformative missions involving technological and social solutions.
} 
emphasize that the system's output is the changes in "socio-material relations that connect ideas, objects, activities and people" (Pel et al., 2020, p. 3), notably networks and institutions, which are supported by the material (Pel et al., 2020b; Terstriep et al., 2020). Considering that both technological and social innovations are key to completing missions, the MIS perspective should aim to include any type of technological, organizational, behavioral or institutional innovative outputs.

In this paper, we show that the inclusion of socially innovative solutions is not the only complication in studying missions from a systems perspective. Issues such as the increased wickedness and transformative nature, temporality, systems embedding, and the centrality of problem and solutiondirectionality pose challenges that an MIS approach needs to address. In line with these challenges, we define an MIS as "a temporary semi-coherent configuration of different innovation system structures that affect the development and diffusion of solutions to a mission that is defined and governed by a mission arena of different stakeholders". In this sense, mission solutions involve technologically and socially innovative solutions, as well as the destabilization of harmful technologies and practices. The mission arena, a concept described in Section 4.2.1, refers to actors that are engaged in the highly political and often heavily contested process of mission governance; we describe this governance process as mobilizing, directing and aligning existing innovation system structures into a semi-coherent ${ }^{2}$ ensemble that aims to pursue the mission.

Building on the structural-functional approach, this paper not only develops a first approach to studying the MIS which deals with these challenges, but it also illustrates the usefulness of the MIS by applying it to the case of the Dutch Green Deal mission on sustainable maritime transportation. Although each mission is unique (Janssen et al., 2021), the Dutch Green Deal provides a good case for our framework, since it involves a goal-oriented collaboration process between different actor types that, despite contestation, try to develop different types of innovative mission solutions. Our approach first aims to identify the systemic barriers ${ }^{3}$ that inhibit a 'well-performing MIS', in other words an MIS that develops and diffuses innovative solutions sufficiently rapidly to meet the mission's time-bound goals. The approach then assesses, ex ante, whether the mission governance actions that the arena participants engage in adequately target the MIS barriers and effectively enhance the performance of the MIS. This assessment allows us to provide recommendations for more effective mission governance. Our framework aims to answer research questions such as 'Do the mission arena's governance actions adequately target the systemic barriers in the respective MIS?'.

In Section 2, we combine the literature on MIP with innovation systems and transition studies literature to identify the conceptual challenges that arise from combining these literatures into the concept of MIS. In Section 3, we discuss the shortcomings of the TIS structural-functional approach in meeting these challenges, and we justify the need for an MIS approach. We then develop the structural-functional MIS approach in Section 4. Section 5 introduces the empirical case and the methods used for our MIS approach. Section 6 provides the analysis of the case. In Section 7, we discuss our findings, indicate the directions for further research and reflect on the generalizability of the MIS approach. Section 8 provides our conclusion.

\section{The challenges of an innovation systems perspective around missions}

\subsection{Wickedness of challenge-led missions}

Wanzenböck et al. (2020, p. 3) view MIP as "a directional policy that starts from the perspective of a societal problem, and focuses on the formulation and implementation of a goal-oriented strategy by

\footnotetext{
${ }^{2}$ As different actors have different forms of appraisal (Loorbach, 2010; Smith and Stirling, 2007).

${ }^{3}$ Also referred to as systemic problems, failures or bottlenecks. To prevent confusion with the societal problem concept, we opted for using the term systemic barriers instead of systemic problems.
} 
acknowledging the degree of wickedness of the underlying challenge, and the active role of policy in ensuring coordinated action and legitimacy of both problems and innovative solutions across multiple actors". This interpretation of MIP assumes that missions are wicked both in terms of the societal problems that they tackle and in terms of the solutions to these problems. This means that both a mission's problems and solutions are contested, are highly complex, and involve uncertainty (see Alford \& Head, 2017; Wanzenböck et al., 2020).

These wicked mission characteristics have several implications for conceptualizing an MIS. First, a holistic MIS analysis not only requires a study of the innovative solutions to the mission, which is the typical focus of innovation systems perspectives, but also benefits from studying the formulation process of the mission and the different societal problems involved that 'compete' for legitimacy and prioritization (Alford \& Head, 2015; Wanzenböck et al., 2020). Second, an MIS requires the development and diffusion of different sets of technologically and socially innovative solutions, each interacting in various ways (Azar \& Sandén, 2011). Furthermore, these solutions include not only the development and implementation of the 'new', but also the replacement and phasing out - or exnovation (David, 2017) - of the 'old' problematic practices and technologies (Kivimaa \& Kern, 2016). This makes MIP inherently a transformative policy rather than only an innovation policy, regardless of the radicality of the transformation required (Janssen et al., 2021). Overall, this means that coordination of solutions and phase-out becomes more important in an MIS, and that contestation features prominently in terms of problem framings, selection of innovation pathways, and phasing out of existing practices and technologies. Finally, the uncertainty involved in missions, i.e., the way in which the problem and solution develop in relation to each other, warrants critical and timely reflexivity (Smith and Stirling, 2007; Weber and Rohracher, 2012) within the MIS.

\subsection{Temporality and embeddedness of missions}

Proper missions have a goal that is time-bound; typically this is a medium- to long-term goal, meaning 10-30 years ahead, with various milestones (Mazzucato, 2018). In other words, MISs are by definition temporary: they emerge once the mission formulation process commences, and they end when the goal is completed or the time has run out. Although technologies also come and go, this explicit temporality of the MIS makes it unique amongst innovation systems perspectives (Frenken, 2017).

However, missions rarely emerge 'from scratch'; instead, problems have already been legitimized and framed in some ways, and relevant solutions may be at different stages of development. This implies that temporary MIS are embedded within and aim to build on existing (regional, sectoral, national and technological) innovation system structures to mobilize available system resources to achieve the mission (Frenken, 2017), see Figure 1. For example, the new Horizon Europe missions did not originate in a vacuum. Instead, they were built on previous problem framings and solutions that had been developed and diffused by existing innovation system structures (Wanzenböck et al., 2020). This illustrates that the success of an MIS in generating innovative solutions strongly depends on the institutional structures, actors, networks and material infrastructure on which it builds. Hence, an MIS approach should pay explicit attention to the mission's governance (i.e., the mission arena) and the innovation system structures in which it is embedded and that it aims to mobilize.

\subsection{Directionality of missions}

The most fundamental implication of missions may well be the directionality they provide (Mazzucato, 2017; Robinson \& Mazzucato, 2019); this distinguishes it from the typically more open-ended, bottomup transformative innovation policy (Haddad et al., 2019; Schot \& Steinmueller, 2018; Wanzenböck et al., 2020). Directionality can be provided in different degrees, ranging from open problem framings to specific mission formulations that exclude a wide range of solutions. Finding a balance between solution diversity and focus is a typical challenge for practitioners (Wesseling et al., 2020). Regardless of this sliding scale, a mission's directionality intervenes in a complex set of different solution 
interactions that interact in positive, negative or neutral, and unilateral or multilateral ways (see Sandén \& Hillman, 2011). Azar and Sandén (2011) argue that any problem framing favors some of these solutions over others, for example because they can or cannot meet certain targets, belong to or are excluded from a certain set of solutions, or are at a certain level of development. Consequently, missions may purposefully but also involuntarily shape what clusters of technological and social solutions, or solution pathways, will emerge. To safeguard the directionality that missions provide, high levels of well-informed reflexivity and coordination are needed in the MIS, so as to prevent unsolicited exclusion of potentially valuable solutions.

Providing directionality is thus a highly normative and politically laden process; Schlaile et al. (2017) argue that this is something that the transition literature currently insufficiently takes into account. Various authors argue that directionality needs to result from an inclusive multi-stakeholder process that not only includes governments, NGOs, industry, knowledge institutes and intermediaries, but also citizens (Bickerstaff \& Walker, 2005; Loorbach, 2010; Mazzucato, 2018; Schot \& Steinmueller, 2018; Smith \& Stirling, 2007). Powerful actors with vested interests, such as industry associations, should be involved in this governance process carefully as they are more likely to contest the destabilization of the status quo than individual firms (Hillman \& Hitt, 1999; Wesseling et al., 2014).

\section{The shortcomings of the TIS structural-functional approach to studying missions}

Different authors have argued that existing innovation systems and transition frameworks are currently insufficiently equipped to understand and systematically assess the impact of transformative mission policies and governance actions (Ghazinoory et al., 2020; Haddad \& Bergek, 2020; Hekkert et al., 2020), due to the above-mentioned challenges. Consequently, in the following sections we will develop the MIS approach in a way that deals with these challenges.

To develop the MIS approach, we take as a starting point a clear operational and systematic approach that adopts a systems perspective and has the potential to understand the impact of contextual structures (Bergek et al., 2015); this is the structural-functional approach that is normally applied to TIS (Bergek et al., 2008; Hekkert et al., 2007). This approach assesses 'key innovation activities', called 'system functions', to identify weaknesses in the system's performance and to uncover the systemic barriers that cause these weaknesses. A TIS's analytical focus on a single technological solution, however, differs from an MIS's focus on societal problems and the corresponding sets of interrelated solutions. Moreover, a TIS is not a holistic transition framework, as it only looks at the new innovation and not that which is being replaced. Consequently, these perspectives have different conceptions of wickedness, temporality, embeddedness, and directionality (see Table 1), which translate into several adaptations of the structural-function approach when studying an MIS (see Section 4.3).

Other adaptations of the structural-functional approach have been undertaken by Ghazinoory et al. (2020), in their concept of a 'Problem-oriented Innovation System' (PIS), and by Haddad and Bergek (2020), in their assessment of transformative innovation policy at the sectoral level. The main difference between the MIS and Ghazinoory et al.'s (2020) PIS perspective is that by focusing on a societal problem, the PIS delineation becomes very diffuse. Several actors may support innovative solutions to a societal problem, making them part of the same PIS, but these actors may not share many other structural system components. They may not interact or share many 'rules of the game', resulting in a system only in the analytical sense but not in the empirical sense (see Markard et al., 2015). This is different from an MIS, where, as we explain in Section 4.2.1, a mission arena aims to mobilize these existing actors, networks, institutions and materiality, and to realign these existing innovation system structures into a well-functioning MIS, directed by a concrete, actionable, and broadly supported mission. 
Table 1: overview of the differences between TIS and MIS along various analytical dimensions

\begin{tabular}{|l|l|l|}
\hline Dimension & TIS & MIS \\
\hline 'Wickedness' & $\begin{array}{l}\text { Involves uncertainty, complexity, and } \\
\text { contestation within the scope of a } \\
\text { single solution, involving competition } \\
\text { between technological designs. } \\
\text { Overlooks regime resistance. }\end{array}$ & $\begin{array}{l}\text { Involves uncertainty, complexity and } \\
\text { contestation in terms of (a) the problem } \\
\text { definition and prioritization, and (b) the } \\
\text { solution scope in which sets of different } \\
\text { types of solutions interact. Contestation } \\
\text { translates into the risk of capture by the } \\
\text { regime. }\end{array}$ \\
\hline $\begin{array}{l}\text { Temporality and } \\
\text { embeddedness }\end{array}$ & $\begin{array}{l}\text { Technologies emerge, mature and } \\
\text { phase out, in one or more sectoral } \\
\text { contexts. }\end{array}$ & $\begin{array}{l}\text { Missions are formulated and completed } \\
\text { or discontinued. They emerge around } \\
\text { societal problems and aim to mobilize } \\
\text { existing innovation system structures } \\
\text { that can be part of the regime. }\end{array}$ \\
\hline Directionality & $\begin{array}{l}\text { Encompasses the attention for the } \\
\text { focal technology and competition } \\
\text { between underlying designs. Overlooks } \\
\text { replacement effects. }\end{array}$ & $\begin{array}{l}\text { Encompasses the attention for the } \\
\text { mission formulation and underlying } \\
\text { societal problem(s), as well as attention } \\
\text { for the competing sets of innovative and } \\
\text { 'phase-out' solutions. }\end{array}$ \\
\hline
\end{tabular}

\section{A structural-functional approach to MIS}

The structural-functional approach to studying TIS (Bergek et al., 2008; Hekkert et al., 2007) distinguishes various analytical steps. According to Wieczorek and Hekkert (2012), these include the analysis of the system's structural components, its system functions, and systemic barriers, before systemic policy instruments (or in our case mission governance actions) can be recommended that overcome the barriers so that the TIS's performance improves. They use 'diagnostic questions' to operationalize their concepts and guide their analysis. Building on this structural-functional approach, and bringing in the transition, governance and MIP literature, we outline the analytical steps below as well as the associated diagnostic questions by which we structure our MIS approach.

\subsection{Problem-solution diagnosis}

As a first step of studying an MIS, we map out the full scope and complexity of the mission. This means identifying what societal problems and solutions are involved in the mission. Although missions typically focus on a single societal problem (Mazzucato, 2018; Wanzenböck et al., 2020), other societal problems tend to be involved via framework conditions that define what solutions are desirable. A good example is the Dutch Delta Works mission for water safety, for which solutions were required to comply with framework conditions related to maritime transportation, ecology and cultural heritage (Wesseling \& Edquist, 2018). The way in which different societal problems are included and prioritized in the mission formulation constitutes what we call 'problem directionality' and is assessed as part of the system functions analysis.

The problem directionality affects what solutions are relevant for the mission. 'Solution-directionality' refers to the factors that determine how stakeholders search for and invest in the solutions they deem promising for fulfilling the mission. Conditions are determined by regulative, normative and culturalcognitive institutions (Scott, 2014) that are already in place and that the mission arena may attempt to influence or complement.

After having inventoried the different societal problems related to the mission, the researcher should explore what technical and social solutions are relevant to the mission and how these solutions interrelate; see Sandén and Hillman (2011) for a framework to study this. Table 2 lists examples of diagnostic questions relevant to the problem-solution diagnosis. Note that this inventorying of 
problems and solutions related to the mission, is different from assessing the problem and solution directionality within the system (see 4.3).

Table 2: Examples of diagnostic questions for the problem-solution diagnosis

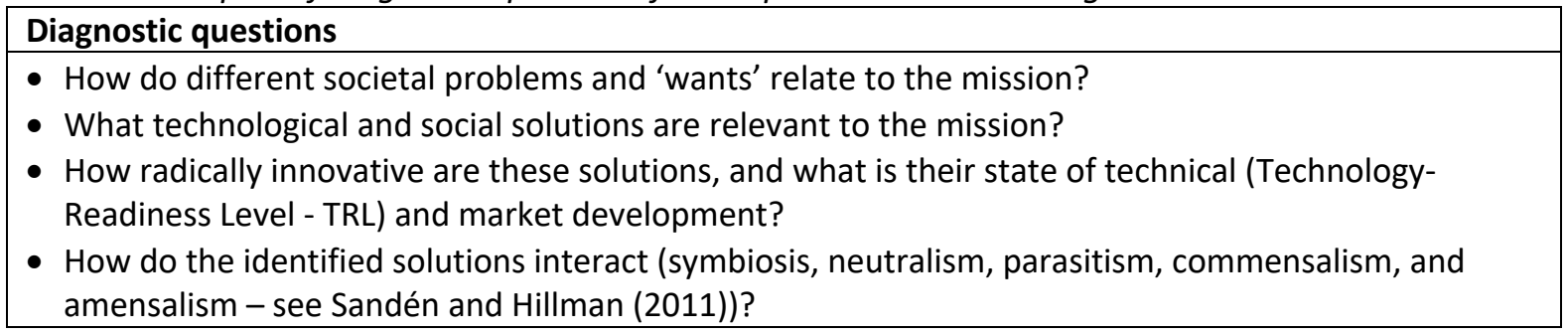

\subsection{Structural analysis}

When the problem-solution context is clear, the second step in our MIS analysis is to explore the structural components, in other words the actors, institutions, networks, and materiality of an MIS (Bergek et al., 2015). This immediately raises the question of delineation: what is and what is not part of an MIS? We distinguish the mission arena and the overall MIS.

\subsection{1 mission arena}

The mission arena ${ }^{4}$ refers to the actors that are engaged in the highly political and often heavily contested process of mission governance. We describe mission governance as providing direction to the MIS as well as mobilizing and aligning existing innovation system structures into a semi-coherent ${ }^{5}$ ensemble that aims to pursue the mission. This direction is provided by the mission goal and by complementary governance actions. The arena metaphor is taken from political and social theory to emphasize its temporary, actor-dependent and contested nature (Fink, 1996; Jørgensen, 2012). This is particularly suitable for mission arenas that aim to govern an MIS, as both proponents and opponents of swift transformative mission action vie for the acceptance of their framing of the mission's problems and solutions and the consequent course of action (Wanzenböck et al., 2020). Based on MIPO's ongoing missions work, ${ }^{6}$ we distinguish four main tasks to mission governance: 1 ) setting up the mission arena, 2) formulating the mission, 3) mobilizing the MIS components via mission governance actions, and 4) continued, reflexive mission governance. Different actors may actively contribute to these different tasks in the arena over time.

Setting up the mission arena is the process in which the mission governance structure is decided. This includes the question 'Who is in?', which ties in with questions such as 'How to develop networks that enable effective mobilization and redirection of existing innovation systems structures?', 'How to make decisions?', and 'How to deal with power imbalances?'. There are different perspectives and approaches to mission governance, as there are to transition governance (Stirling, 2008; Vo $\beta$ \& Kemp, 2006). For example, Smith \& Stirling (2007) distinguish an 'outside' and an 'inside' perspective, in which the 'outside' governance perspective takes a managerial approach aimed at objectifying the socio-technical system in which it aims to intervene, whereas the 'inside' perspective and political approach is oriented towards co-constituting the socio-technical system. They argue that these perspectives translate into various governance strategies, ranging from strategies to deal with the input and output of appraisal, with power, and with different actor framings, to strategies to obtain stakeholders' appraisal and commitment, which are necessary for a well-functioning MIS. It is too early to provide prescriptive recommendations on how to establish the mission arena, but by placing the

\footnotetext{
${ }^{4}$ Building on Loorbach's (2010) notion of transition arena.

${ }^{5}$ As different actors have different forms of appraisal (Loorbach, 2010; Smith \& Stirling, 2007).

${ }^{6} \mathrm{MIPO}$, the Mission-oriented Innovation Policy Observatory engages in various mission workshops (see e.g., Wesseling et al., n.d.) and studies (see Janssen et al. (2020) for MIPO's position paper).
} 
mission arena at the heart of the MIS analysis, we may develop a better understanding of the mission arena's governance strategies and how these affect the overall functioning of the MIS.

Formulating the mission refers to the prioritization of societal problems and translating them into an ambitious and actionable mission that provides direction to the overall MIS. Since societal-challengeled missions typically require the transformation of existing socio-technical systems (Wanzenböck et al., 2020), the mission goals will typically oppose the expectations and visions of regime actors, leading to conflict with powerful vested interests (Loorbach, 2010).

This inherent conflict needs to be considered in the deliberation methods employed in the mission arena. Deliberation is defined as "the process by which participants interact, engage in considered debate, and modify their views based on information, shared views, and respect for different perspectives" (Bickerstaff \& Walker, 2005, p. 2124). The Habermasian ideal speech situation, in which all stakeholders are fully and equally informed and empowered to express their interests, and in which debates are settled by sound argumentation and testable claims, seems therefore inadequate as it ignores the inherent power imbalances between stakeholders (Bickerstaff \& Walker, 2005). This is why transition-oriented governance approaches such as Transition Management argue for selective participation in the arena, involving mostly proponents of transition - including willing regime players as they can be a potent transition force (Christoff, 2006; Kattel \& Mazzucato, 2018; Wesseling et al., 2014) - in order to prevent capture and delay by the opposition (Loorbach, 2010). Regardless, transition governance continues to struggle with inclusivity, social learning, and regime persistence (Loorbach et al., 2017). Empirical studies are needed to explore the effects of involving regime players in the mission arena.

Mobilizing the MIS components via mission governance actions requires an overall mission agenda or action plan that includes not only the activities that existing innovation system structures need to pursue, but also the governance actions that incentivize and enable these structures to undertake such activities. We refer to 'mission governance actions' as all the measures by which the mission arena aims to mobilize and align the MIS components to improve the MIS performance. They include mission-oriented innovation policy instruments implemented by governmental organizations, as well as measures to mobilize system components, implemented by other arena stakeholders. Examples include public funding or taxation schemes to incentivize and direct industrial innovation, stakeholders reallocating their infrastructure or material resources to enable the innovation efforts of third parties, networking organizations engaging in information-sharing processes to foster solution development or uptake, and educational organizations providing training and re-integration programs to employees that stand to lose from the transition, to ease the burden of transition. Such measures taken by mission arena members are aimed at mobilizing existing innovation system structures to support the overall functioning of the MIS and require a well-connected, embedded and empowered mission arena.

Continued, reflexive mission governance is required throughout the duration of the mission. This involves ensuring that mission progress is monitored and evaluated; reflecting on how the translation of different interacting solutions into solution pathways is coordinated; ensuring that the mission is reformulated and the MIS redirected if it no longer captures the most relevant societal problems; and ensuring that mission governance actions are adapted or existing institutions changed if the solution pathways developed are evaluated as inadequate in relation to the mission goal. Hence, the continued governance should take into account how societal problems change over time, just like the development trajectories of sets of solutions and related stakeholder appraisals (Stirling, 2008; Smith \& Stirling, 2007) - both within and outside the mission arena (Jørgensen, 2012). This requires both broad and empowered deliberation (Jørgensen, 2012; Smith \& Stirling, 2007) and the ability "to draw on a monitoring, anticipation, evaluation and impact assessment system ("strategic intelligence") that 
provides the analytical and forward-looking basis for reflexive discourses and adaptive policies" (Weber \& Rohracher, 2012, p. 1044; Fogelberg \& Sandén, 2008; Loorbach, 2010; Loorbach et al., 2017).

\subsubsection{Defining the MIS}

For a discussion on what comprises the overall MIS, we build on existing socio-technical and innovation systems perspectives. An innovation system is typically defined by its structural components, the actors, networks, institutions, and materiality or technology, that affect the rate and direction of the innovation - often interpreted as technological change (Carlsson \& Stankiewicz, 1991; Edquist, 2004; Edquist \& Lundvall, 1993; Hekkert et al., 2007; Malerba \& Orsenigo, 1997). Although these broader definitions do not exclude innovation-opposing forces from the innovation system, socio-technical transition perspectives, such as the Multi-Level Perspective, have often criticized innovation systems perspectives for under-conceptualizing the forces of stability, i.e. the regime, that have a profound effect on both the rate and the direction of innovation (Geels, 2004; Markard et al., 2015).

In line with previous, broader innovation system definitions, we regard the overall MIS as the actors, networks, institutions, and materiality that affect the rate and direction of both technologically and socially innovative solutions to the mission, including both supportive and opposing forces of change. These structural components influence innovative mission solutions, either directly or indirectly, purposefully or inadvertently, and for the sake of the mission's progress, for economic gains, or for other purposes. Hence, existing import tariffs that inadvertently restrict the import of innovative mission solutions are part of the MIS, as are entrepreneurs developing innovative solutions for financial gain. The mission arena aims to align and mobilize these structural components to foster the development and diffusion of innovative solutions; for example, actors in the arena may lobby to remove or adapt the import tariffs to benefit the performance of the MIS.

To highlight the temporary, contested, and embedded nature of MIS, we define an MIS as " $a$ temporary semi-coherent configuration of different innovation system structures that affect the development and diffusion of solutions to a mission that is defined and governed by a mission arena of different stakeholders". Figure 1 visualizes how the mission arena aims to mobilize and align existing innovation systems structures that affect the mission's success, in pursuit of completing the mission.

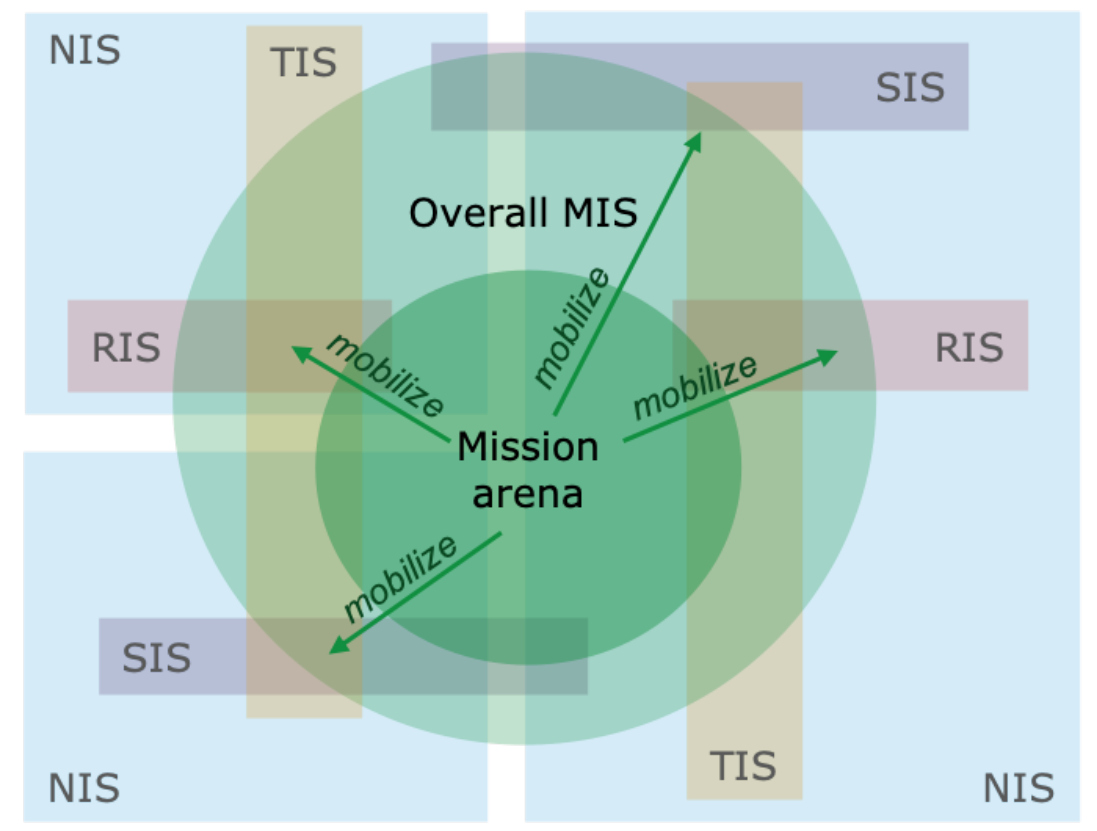


Figure 1: The mission arena aiming to mobilize other, existing innovation systems structured into an overall, well-performing MIS

As the mission arena is increasingly successful at redirecting and mobilizing the contextual innovation system structures, the MIS itself becomes more structured; its institutions become more institutionalized, actors outside the arena become more dedicated, and solutions become better developed and diffused. An MIS analysis should emphasize such institutional alignment in its structural analysis, for example by using the diagnostic questions in Table 3. As this table shows, the structural analysis focuses on the structural components of the system, including the mission arena, but not on assessing the processes or activities that these structures engage in, as this is part of the system functions analysis.

Table 3: Examples of diagnostic questions for the structural analysis

Diagnostic questions

- What actors are part of the mission arena and contribute to

(a) the mission formulation,

(b) mobilizing other MIS components in pursuit of the mission, and

(c) the continued governance of the mission?

- What actors, networks, institutions, and materiality support the development and diffusion of the mission's solution, including the phasing out of harmful goods and practices?

- How does the mission arena align with existing formal and informal institutional structures related to the mission?

\subsection{System functions}

The system functions developed to study TIS (Bergek et al., 2008; Hekkert et al., 2007) define a set of 'key innovation activities' that result from the structural system components identified in Step 2. The system functions are generic enough to also apply to innovation systems characterized by a sector (Wesseling \& Van der Vooren, 2017), by a societal problem (Ghazinoory et al., 2020), by sustainability transition pathways (Haddad \& Bergek, 2020), or as we show here, by a mission. As described previously, applying the system functions approach from TIS to MIS should address several MIPspecific challenges. This has driven us to develop an adapted and reinterpreted set of MIS functions and associated diagnostic questions to assess them (see Table 4).

The concept of the mission arena that aims to mobilize existing systems structures in which it is embedded and foster transformative change has several implications.

First, 'mission solutions' involve both innovations and the phasing out of old, harmful practices and technologies; therefore, the system functions should not only reflect key innovation activities that capture 'the new', but should be broadened to include transformation activities related to destabilization or phasing out of 'the old'. As shown in Table 4, we posit that all such destabilizing activities can be traced back to the counterpart of existing system functions. A policy mandating phasing out an existing technology or levying additional taxes may be interpreted as an example of market destabilization, i.e., the counterpart of market formation, resulting in the system function 'market formation and destabilization' that reflects a key transformation activity instead of just an innovation activity. In the same way, the TIS function 'creation of legitimacy' has been extended to the transformation activity 'creation and withdrawal of legitimacy', to encompass the delegitimization of harmful practices and technology that is an important part of destabilizing the regime (Isoaho \& Markard, 2020; Rosenbloom, 2018; Turnheim \& Geels, 2012). 'Resource mobilization' is reinterpreted as 'resource (re)allocation' for the same purpose.

Second, the mission arena aims to influence the direction in which existing innovation system structures develop and diffuse innovation, and this involves taking mission governance actions that 
Table 4: description of system functions for MIS analysis and corresponding diagnostic questions, building on previous work on TIS-related system functions, including Bergek et al. (2008); Hekkert et al. (2007); Suurs (2009); and Wieczorek and Hekkert (2012)

\begin{tabular}{|c|c|c|}
\hline System function & MIS interpretation & Examples of diagnostic questions \\
\hline $\begin{array}{l}\text { SF1: Entrepreneurial } \\
\text { activities }\end{array}$ & $\begin{array}{l}\text { Experiments with solutions (or clusters of solutions) to enable } \\
\text { learning; entering markets for new solutions; engaging in } \\
\text { business model innovations to foster the diffusion of } \\
\text { solutions. }\end{array}$ & $\begin{array}{l}\text { - Are experiments to develop existing and new solutions conducted fast enough } \\
\text { to complete the mission? } \\
\text { - Is production capacity created fast enough? }\end{array}$ \\
\hline $\begin{array}{l}\text { SF2: Knowledge } \\
\text { development }\end{array}$ & $\begin{array}{l}\text { Learning by searching and by 'doing', resulting in } \\
\text { development and better understanding of new technical and } \\
\text { social knowledge on problems and solutions, through R\&D, } \\
\text { social research and behavioral science research. }\end{array}$ & $\begin{array}{l}\text { - Is sufficient knowledge developed to understand the societal problem and the } \\
\text { harmful effects of innovative goods and practices? } \\
\text { - Is knowledge to develop existing and new solutions created fast enough to } \\
\text { complete the mission? } \\
\text { - Is knowledge created to help actors to unlearn practices harmful to the mission } \\
\text { sufficiently rapidly? }\end{array}$ \\
\hline SF3: Knowledge diffusion & $\begin{array}{l}\text { Stakeholder meetings, conferences, governance structures, } \\
\text { public consultations, mission progress reports and other } \\
\text { forms of disseminating technical and social knowledge for the } \\
\text { mission's solutions and societal problems. }\end{array}$ & $\begin{array}{l}\text { - Is knowledge about the societal problem diffused sufficiently to formulate a } \\
\text { broadly supported, clear, time-bound and ambitious mission? } \\
\text { - Is knowledge to develop and use solutions diffused amongst all stakeholders } \\
\text { sufficiently rapidly to complete the mission? }\end{array}$ \\
\hline SF4: Providing directional & $\begin{array}{l}\text { Besides pre-existing institutional structures in the context of } \\
\text { the mission arena, the mission arena is central to providing } \\
\text { direction and mobilizing support from the existing innovation } \\
\text { system structures that comprise the overall MIS. }\end{array}$ & $\begin{array}{l}\text { - Have the governance structures been set up to establish an influential and } \\
\text { well-embedded mission arena, in which different stakeholder interests are } \\
\text { reflected, to direct and help mobilize the overall MIS? } \\
\text { - Is an inside/political or outside/managerial governance approach taken? }\end{array}$ \\
\hline $\begin{array}{l}\text { 4A: Problem } \\
\text { directionality }\end{array}$ & $\begin{array}{l}\text { The direction provided to stakeholders' societal problem } \\
\text { conceptions and the level of priority they give it. }\end{array}$ & $\begin{array}{l}\text { - Do stakeholders prioritize the mission's societal problems and framework } \\
\text { conditions in relation to other societal problems and demands? }\end{array}$ \\
\hline $\begin{array}{l}\text { 4B: Solution- } \\
\text { directionality }\end{array}$ & $\begin{array}{l}\text { The direction given, both by existing system structures and } \\
\text { the mission arena, to the search for new and further } \\
\text { development of existing technological and social solutions, as } \\
\text { well as the coordination efforts needed to identify, select, } \\
\text { and exploit synergetic sets of solutions to the mission. }\end{array}$ & $\begin{array}{l}\text { - Do stakeholders know what solutions are necessary to complete the mission } \\
\text { (both innovative solutions and phasing-out of old practices and technologies)? } \\
\text { - Do stakeholders agree on what the necessary solutions are, or do they agree } \\
\text { that they do not know all necessary solutions yet? } \\
\text { - What solution directions are currently being prioritized over others, and by } \\
\text { what system structures or system contextual factors? } \\
\text { - Is a dominant set of solutions emerging? } \\
\text { - Do stakeholders sufficiently recognize and exploit the interdependencies } \\
\text { between different solutions? }\end{array}$ \\
\hline
\end{tabular}




\begin{tabular}{|c|c|c|}
\hline System function & MIS interpretation & Examples of diagnostic questions \\
\hline 4C: Reflexive governance & $\begin{array}{l}\text { Reflexive deliberation, monitoring, anticipation, evaluation } \\
\text { and impact assessment procedures; these provide the } \\
\text { analytical and forward-looking basis for redirecting the } \\
\text { system's problem framing and search for solutions based on } \\
\text { lessons learned and changing context. Reflexive governance } \\
\text { can be seen as second-order directionality, and it can be } \\
\text { initiated by the mission arena or by critical outsiders. }\end{array}$ & $\begin{array}{l}\text { - Is the mission's progress monitored transparently (e.g., by a dedicated } \\
\text { taskforce) and is the MIS on track to meet the mission? } \\
\text { - If not, have sufficient measures been taken to catch up? } \\
\text { - Is the impact and relevance of the mission governance actions regularly } \\
\text { evaluated and, if necessary, are they adequately redesigned? } \\
\text { - Does multi-stakeholder deliberation take place to assess whether the mission } \\
\text { still adequately captures a pressing societal problem? } \\
\text { - If it does not, is progress being made towards reorienting the mission? }\end{array}$ \\
\hline $\begin{array}{l}\text { SF5: Market formation } \\
\text { and destabilization }\end{array}$ & $\begin{array}{l}\text { Creating a niche market and upscaling support for technical } \\
\text { and social solutions; phasing out or destabilizing markets for } \\
\text { practices and technologies harmful to the mission. }\end{array}$ & $\begin{array}{l}\text { - Do formal or informal policies support the sufficiently rapid diffusion of } \\
\text { innovative solutions and the phasing out of harmful technologies and practices } \\
\text { to complete the mission? } \\
\text { - Do stakeholders adopt the solutions sufficiently rapidly? } \\
\text { - Do stakeholders abandon harmful practices and technologies sufficiently } \\
\text { rapidly? }\end{array}$ \\
\hline $\begin{array}{l}\text { SF6: Resources } \\
\text { (re)allocation }\end{array}$ & $\begin{array}{l}\text { Mobilization of human, financial and material resources to } \\
\text { enable all other system functions. }\end{array}$ & $\begin{array}{l}\text { - Have sufficient human, financial and material resources been mobilized to fulfil } \\
\text { the other system functions? } \\
\text { - Have resources been withdrawn from harmful practices and technologies to } \\
\text { stop their continuation? }\end{array}$ \\
\hline $\begin{array}{l}\text { SF7: Creation and } \\
\text { withdrawal of legitimacy }\end{array}$ & $\begin{array}{l}\text { Creating legitimacy for prioritizing (a) the problem and (b) the } \\
\text { development and diffusion of the solutions, at the cost of } \\
\text { harmful practices and technologies. }\end{array}$ & $\begin{array}{l}\text { - Do stakeholder groups and the public vocally support the mission's societal } \\
\text { problem and solutions? } \\
\text { - Do stakeholders attempt to generate more support from the public or from } \\
\text { other actors for the mission's societal problem and solutions (including } \\
\text { lobbying to withdraw actors' support for harmful practices and technologies)? }\end{array}$ \\
\hline
\end{tabular}


influence the directionality (SF4) in the MIS. Our adapted system functions should capture directionality on both the problem side (SF4a) and solution side (SF4b) of the MIS, ${ }^{7}$ as well as the reflexive governance (SF4c) processes that are typically initiated by the mission arena. Table 4 provides a detailed interpretation of the original system function 'guidance of the search'. Mission goals also provide a clearer reference from which to assess the system functions (allowing for questions such as "Are system functions developed 'sufficiently rapidly to complete the mission'?" see Table 4). The lack of such a reference point is known to increase the likelihood of a subjectivity bias in TIS studies, when rating the system function performance.

Third, solution-directionality is affected specifically by the increased scope and complexity of the MIS, as a result of including sets of interacting technological and social solutions. The presence of these solution sets begs the question of whether the system functions should be assessed per individual mission solution, per set of solutions or mission-generically. In this paper, we take the latter approach to manage complexity - assessing system functions for mission solutions in general while critically reflecting on solution-type-specific exceptions. The broader MIS scope also raises the question of whether system functions can sufficiently capture social innovation processes. Ghazinoory et al. (2020) and Haddad and Bergek (2020) tentatively showed that adapted system functions are capable of doing so. Interrelatedness of solutions requires mission arena processes of solution coordination in solution pathways that are overlooked in a TIS analysis (Bergek et al., 2015; Haddad \& Bergek, 2020).

The TIS functions also do not capture well the mission arena's continued, reflexive governance processes (SF4c), which were detailed in the previous section. As these processes are key to mission governance (Janssen et al., 2020; Mazzucato, 2018), we add them as a third dimension to the system function 'providing directionality'. Such reflexive governance may result in a readjustment of the MIS's problem or solution-directionality as well as a readjustment of the supportive mission governance actions.

Similar to the system functions approach by Suurs and Hekkert (2009), we distinguish between on the one hand positive system function fulfillment, i.e., innovation activities that contribute to meeting the mission goal, such as more support for innovative solutions or phasing out of harmful practices, and on the other hand negative fulfilment, i.e., a decrease in these activities, such as reduced mission legitimacy or an increase in harmful practices.

\subsection{Systemic barriers analysis}

Systemic barriers are structural components (actors, networks, institutions, or materiality) that are missing or unable to support the system functions, thus hampering the functioning of the overall system (Wieczorek \& Hekkert, 2012). The origin of these barriers can typically be traced to the regime (Wesseling \& Van der Vooren, 2017). Different, interrelated systemic barriers may result in systemic lock-in (Ibid.)

\subsection{Reflection on the impact of the mission arena's planned governance actions on the overall MIS} The innovation systems literature refers to systemic instruments as such policy or governance actions that aim to address the abovementioned systemic barriers (Smits \& Kuhlmann, 2004). Effective systemic actions should be targeted at the root causes of barriers that prevent innovation system development (Wesseling \& Van der Vooren, 2017). In the context of MIS, we understand systemic instruments as the mission governance actions that the mission arena participants have committed to, in support of the mission's pursuit.

\footnotetext{
${ }^{7}$ This distinction between problem and solution side makes the difference more subtle between system functions 'problem directionality' ('Do stakeholders prioritize the mission's problem over other problems?') and 'creation of legitimacy' ('Do stakeholders support and lobby for the mission's problem?').
} 
We use the rationale of systemic instruments that tackle barriers to improve MIS performance, to enable ex-ante, formative evaluation of the mission governance actions, which the mission arena participants are committed to. Hence, instead of assessing ex ante the likely impact of a mix of governance actions based on the mix' design criteria, such as consistency and coherence (Howlett \& Rayner, 2013, 2007), ${ }^{8}$ our MIS approach starts from an additionality perspective, stressing that the MIS is already engaging in various innovation activities and that the mix of actions should focus on resolving the remaining MIS barriers in order to effectively and efficiently boost the performance of the MIS. To assess whether the MIS barriers are all adequately targeted, we compare them with the mission governance actions.

Formative recommendations follow from the MIS barriers that have currently not yet been addressed or that may unintentionally be reinforced by the ongoing or planned mission governance actions. Building on this overarching systemic evaluation rationale, more generic governance recommendations may follow from our approach if no mission governance actions have been formulated yet. Also building on this rationale, it is possible to develop the MIS approach into an expost, summative mission evaluation tool, but this is outside the scope of the current paper.

\section{Methods}

\subsection{Case description}

Taking a single case study approach, we illustrate the applicability of our MIS approach with the case of the Dutch (not European) 'Maritime and Inland Shipping and Ports' Green Deal. Specifically, we focus on the mission to achieve a $20 \%$ reduction in $\mathrm{CO}_{2}$ emissions per maritime short sea shipping operation by 2024 (Van Nieuwenhuizen, 2019) and a 70\% reduction in absolute $\mathrm{CO}_{2}$ emissions in the sector by 2050 (Green Deal, 2019). The mission arena in this case comprises a governance structure in which different types of public and private actors negotiated and signed the 'Green Deal' document, in which not only the mission is specified but also the various commitments of the signees to taking mission governance actions that aim to mobilize and align the overall MIS to develop and diffuse innovative mission solutions more rapidly (Green Deal, 2019). One of these actions is the initiation of a taskforce that represents the signees, and that coordinates, monitors and evaluates the implementation of the Green Deal. Other planned actions involve the implementation of various innovation policy instruments by public organizations, and the mobilization of members of industry networks to contribute to innovative mission solutions (Green Deal, 2019). We tentatively evaluate ex ante ${ }^{9}$ whether this overall set of mission governance actions are effectively targeting the MIS barriers. As such, our approach allows for an assessment of the potential effectiveness of the Green Deal, as perceived from an MIS perspective.

\subsection{Research design}

To analyze this mission, we took a case study approach that is structured by the research steps set out in the Theory section, including:

1. Problem-solutions diagnosis

2. Structural systems analysis

3. System functions analysis

4. Systemic barriers analysis

\footnotetext{
${ }^{8}$ For example, Kivimaa and Kern (2016) argue that if systems transformation is desired, instrument mixes should include both instruments that support the new and instruments that destabilize the old.

${ }^{9}$ We started data collection as early as 8 months after signing the mission agreement, making it difficult to observe the mission arena's full impact on the overall MIS. We have overcome this drawback by taking an 'exante' approach of mission instruments partly planned and partly in the process of implementation.
} 
5. Contrasting planned mission governance actions and the MIS barriers, to identify recommendations for better mission governance

The concepts relevant to these research steps were operationalized via the diagnostic questions listed in Tables 2, 3 and 4. Note that this structural-functional approach based on diagnostic questions (similar to the work by Wieczorek and Hekkert (2012)) aims to provide a static picture of the innovation system, and is different from the history event mapping approach (used for example by Suurs (2009)), which aims to study innovation system developments over time.

We developed a database to apply these diagnostic questions to, and this consists of 27 interview transcripts and, to enable triangulation, a complementary set of scientific publications, newspaper articles, trade magazine articles, websites, company and technology reports, and Dutch policy documents on sustainable maritime transportation (obtained using LexisNexis, Google and Google Scholar, and via our networks). The sample of our interviewees is representative of the Dutch maritime and inland shipping sector and includes two industry associations, six technology suppliers, five shipping companies, three policymakers, three knowledge institutes, one port, one shipyard, one naval architect, one business developer, two financial organizations, and two freight forwarders. Interviewees include both people actively involved in the mission arena, and people who the mission arena affects (or attempts to affect) via its governance actions. The interview data were leading in all research steps, with the exception of the 'solution diagnosis', for which a complementary literature review on sustainable maritime transportation solutions was conducted. Semi-structured interviews proved particularly useful for identifying interrelated MIS barriers, as they allow for building on the diagnostic questions with 'Why?'-type questions.

Semi-open coding was applied to the database, guided by the diagnostic questions (described in Section 4) while allowing for other relevant factors to be identified. This coding process resulted in a total of 1,403 coded textual fragments. A reliability check was applied by two other researchers, resulting in a Krippendorff's Alpha of 0.88 , which is considered reliable (Krippendorff, 2004).

\section{Analysis}

\subsection{Problem-solution diagnosis}

In this section, we first describe the interrelated societal problems associated with the mission statement, before illustrating the breadth of technological and social solutions to the mission, as well as their interactions.

The Dutch Green Deal for 'maritime and inland shipping and ports' was initiated by policymakers in 2018 because the sector was omitted from most environmental policies, such as the Paris climate agreement (Green Deal, 2019). Although the problem of sustainability was high on the agenda of all the stakeholders involved and the Green Deal goals were not negotiated, the lack of economic competitiveness of sustainability solutions was, and continues to be, the major bottleneck to swift transformative action. Reduced mobility is another trade-off for more radical alternative energy carriers such as battery and hydrogen-electric ships. On the other hand, better local air quality is a win-win, in particular for electric propulsion systems.

Our solutions-analysis distinguishes between technological and social solutions (see Appendix I for a detailed overview and description). The main technological solutions to the ship include exhaust gas treatment systems (scrubbers), electric propulsion systems, electrical sensor systems, and efficiency gains within established technologies (e.g., 'low revolutions per minute' propulsion systems). Six main alternative energy carriers were also identified, namely ammonia, batteries, biofuels, hydrogen, Liquid 
Natural Gas (LNG), and methanol. Finally, we identified two major social innovations; the first is efficient shipping routes and speeds, which are supported by sensory technologies and Al tools to determine the most efficient route and speed, and the second is a smarter global production and transportation system. As Appendix I shows, most of these solutions have higher Technology Readiness Levels and have already been proven in an operational (sea or inland) shipping environment. Some incremental solutions, such as scrubbers and LNG ships, are starting to take off on the global market (IGU, 2020; Safety4Sea, 2019) whereas other, more radically innovative solutions need more development and policy support to become competitive (Geertsma \& Krijgsman, 2019; Henningsgård, 2019). From these solutions, different solution-pathways that offer complementary solutions can be identified, but assessment of such pathways lies outside the scope of this research.

\subsection{Structural analysis}

The mission arena consists of the 42 parties $^{10}$ that negotiated and signed the Green Deal, thus committing to specific actions that help to complete the mission (Green Deal, 2019). Various interviewees indicate that the negotiations for the formulation of the Green Deal were dominated by policymakers and industry associations, with a marginalized role for companies; in the end, only four companies (excluding banks and ports) signed the mission (Green Deal, 2019). This approach of indirect company representation via industry associations led to limited mission awareness and commitment by companies to the Green Deal content, even though companies are key actors for solution development, production and, in the maritime sector, adoption. To safeguard the industry's economic competitiveness, the industry associations also negotiated vaguer and noncommittal mission governance actions. Overall, the mission arena seems to have taken an outside, managerial type of governance approach (Smith \& Stirling, 2007) to mobilizing and directing the MIS, thus marginalizing the role of certain stakeholders in its deliberation processes.

The actors in the overall MIS are much more numerous. As indicated by the inventory of clean shipping solutions, knowledge institutes and technology suppliers had already developed various technological solutions independently of the mission. Shipping companies have adopted the more incremental solutions (Environment, 2018; Wärtsilä Corporation, 2020), and various ports have made efforts to research and develop supportive infrastructure (Port of Rotterdam, 2019). Most of these innovation activities have received government support. The Green Deal strives to direct and increase the innovation development and diffusion rate by these MIS components, while at the same time mobilizing less active actors to contribute to the rate of innovation (see the discussion on systemic barriers below).

The Green Deal is embedded in an influential institutional context that supports sustainable short sea shipping. Interviewees indicate the impact of the International Maritime Organization's (IMO) worldwide regulations, the regulations of other nations, and the local regulations in the form of 'Emission Controlled Areas'. The IMO formally aims to halve global shipping emissions by 2050 (IMO, 2020a). To achieve this, the International Chamber of Shipping proposed a $\$ 5 \mathrm{bn}$ fund to design zeroemissions vessels, fed by a \$2 levy on every tonne of fuel (Harrabin, 2019). Progress is slow, however, causing the EU to formulate its own emission-reduction strategy including market-based measures (European Commission, 2019). The Green Deal mission is more ambitious than these IMO and EU targets, but at the same time interviewees note that its success depends more strongly on the institutional structures in which the Green Deal is embedded than on its own mission agreement and supportive governance actions.

\subsection{Functional analysis}

\footnotetext{
${ }^{10} 8$ governmental organizations, 5 port representatives, 9 industry and trade associations, 4 banks, 3 knowledge institutes, 4 companies and 9 other parties.
} 
The MIS contains quite some entrepreneurial activities (SF1) in terms of experimental projects, and many incremental and radical innovations have reached TRL9 (see Appendix I). In terms of business model development and commercialization, activities are limited to incremental innovations. However, such innovations cannot meet the 2050 goal. Thanks to supportive measures, such as accelerator PortXL, some startups - mostly smart technology providers as such firms need lower capital investments - are entering the market with clean innovations (Smits, 2020). So far, the mission governance actions have not added to these entrepreneurial activities, but they are committed to doing so in the future (Green Deal, 2019).

Most interviewees (19/27) stated that particularly knowledge institutes and technology suppliers have developed a great deal of knowledge (SF2) (see e.g., Topsector Energie, 2020), allowing various clean innovations to reach high TRLs, including in the Netherlands. One interviewee indicated that the sector overlooks exploring the social and more transformative innovation of reducing shipping by rethinking the organization of the global production and transportation system. Most interviewees (24/27) indicated knowledge diffusion (SF3) to be high, as a result of strong formal and informal networks and collaborations along the supply chain that serves the relatively small market of short sea shipping. The Green Deal contributes to this knowledge diffusion and aspires to organize more frequent network meetings.

The Green Deal captures the societal problem of climate change in an ambitious mission to reduce $\mathrm{CO}_{2}$ emissions, contributing to problem-directionality (SF4A). However, it does so under the condition of increasing economic competitiveness, listed as the first consideration in the Deal (Green Deal, 2019, p. 3). Nine interviewees indicated that the sector had already started on this course of "green growth" (Ibid.), and that consequently, the mission's impact on problem-directionality was limited.

Although interviewees seem to agree that a range of solutions is necessary to meet the mission, solution-directionality (SF4B) remains weak. Various radically innovative solutions are being developed (see Appendix I), and although many have reached the stage of market introduction, they require substantial further development to become competitive. This range of competing solutions means that shippers and ports are waiting for a dominant design to emerge. However, little selection is taking place. Additionally, the previous Dutch and European push for LNG has led to high sunk development costs by engine manufacturers, making them reluctant to switch once more to other alternative technologies (Baresic et al., 2018). Finally, interviewees indicated that many shippers do not know the best solution for their specific type of ships; concerning alternative energy carriers, they are dependent on new infrastructure that is not yet in place because, as a port representative indicated, there is no demand for it (note the chicken-and-egg problem). Although the mission's ambitious target signals that a cluster of radical technological and social solutions needs to be widely diffused by 2050, ten interviewees indicated that the mission arena might contribute more to solutiondirectionality if it provided information on and assessments of the different solutions that stakeholders need - something the mission arena failed to do adequately. Four interviewed companies (not involved in the mission arena) confirmed that the vague formulation of mission actions contributed little to solution-directionality.

Reflexive governance (SF4C) was low in the overall MIS, as greenhouse gas emissions were not consistently monitored and the EU's and IMO's initiatives were at too early a stage to evaluate and redirect, similar to the Green Deal's mission governance actions. The Green Deal aims to add to reflexivity as industry associations will 'stimulate' their members to report shipping emissions. More importantly, there will be a taskforce responsible for monitoring and evaluating the mission's progress and the effectiveness of its mission governance actions. Although all interviewees indicated the importance of such a taskforce, half of them stressed that the taskforce should have been installed 
immediately and should operate transparently, in order to better maintain stakeholder commitment over the entirety of the mission.

In terms of market formation and destabilization (SF5), the diffusion of clean shipping innovations is largely limited to incremental and add-on solutions, including ships equipped with exhaust gas treatment systems (scrubbers), alternative fuels such as biofuels or LNG, efficiency gains within established technologies, electrical sensor systems, and more effective shipping routes, speeds and fleet use (I\&W, 2019). Some of these solutions are also tentatively being diffused on the global market, for example scrubbers (2,947 ships by 2019 - Safety4Sea, 2019), LNG (541 by 2019 - IGU, 2020) and sensory systems, which have become mainstream in new ships (Kashyap, 2019). Most of these solutions have been diffused in response to market-destabilizing regulations such as emission-control areas and the compulsory monitoring of fuel consumption, that favor the adoption of incremental innovations (EC, 2017; IMO, 2020b). Due to the focus on incremental and add-on innovations, no real phasing out of technology is taking place, other than the replacement of conventional, oil-based marine fuels by LNG and biofuels. An important driver for sustainable shipping is the procurement of the government's shipping fleet. By 2018, 12 of its seafaring ships were powered by $30 \%$ biodiesel and from 2019 onwards the Dutch government started the procurement of 15 hybrid-electric ships that are equipped with electrical sensor and software systems to enable not only efficient shipping, shipping routes, and speeds, but also enhanced hydrodynamics, heat recirculation systems, and solar panels (Rijkswaterstaat, 2020).

Regardless of these market developments, interviewees generally agreed that market formation for sustainable-shipping innovations is weak - particularly for radical innovations - and they provided several reasons. First, other than the aforementioned regulations, eleven interviewees indicated that market-forming policies and destabilizing regulations are insufficient to kick-start the adoption of uncompetitive innovations. Second, both interviewed freight forwarders indicated that they are not willing to pay a premium to shippers for sustainable transportation because they cannot transfer the costs to their customers. Consequently, shippers are unwilling to pay for the implementation of radical sustainable innovations. A third reason is the aforementioned uncertainty regarding the dominant energy carrier and its dependence on infrastructure, resulting in a wait-and-see attitude in shippers (Harrabin, 2019). Finally, three interviewees explained that energy-efficiency solutions, including the social solutions of optimal shipping speeds and routes, are impaired by organizational barriers, since the charterer pays the fuel, taking away the incentive for shippers to adopt sustainable solutions, as they do not enjoy the benefits. Niche markets in which some sustainability premium can be transferred to the end consumer tend to be more high-value, high-tech industries in direct contact with the end consumer (confronting them with visible air pollution), such as the cruising industry (Hennigs et al., 2017). As Section 6.5 will show, the public members of the mission arena have committed to several actions aimed at overcoming these systemic barriers underlying the weak market formation for sustainable shipping solutions.

Interviewees indicated there are no clear barriers in the allocation (or re-allocation) of financial, human or material resources (SF6). The issue remains that, due to the lack of a business model but presence of existing public R\&D support, financial resources are being invested in R\&D and not so much in adoption, even though the interviewed banks are willing to finance. This imbalance is one reason for the many market-ready but uncompetitive innovations that are not being selected in for wider diffusion. All stakeholders consider the mission arena's mobilization of $€ 5$ million in public funding to have little impact, compared to the billions of euros necessary to finance the sector's sustainability transition.

Interviewees agreed that problem-legitimacy (SF7) has politically been high for some time, as even the government's coalition agreement referred to the need for the Green Deal (Regeerakkoord, 2017, 
p. 40). The public however, puts little pressure on the sector as it and its emissions are mostly invisible to them. Solution legitimacy (SF7) has been lobbied for by various solution-specific and generic lobby groups, such as the emission-free shipping association that lobbied for a $\mathrm{CO}_{2}$ tax to finance sustainable innovation (Anink \& Sakko, 2019). Industry associations opposed such more transformative instruments in favour of vaguer mission governance actions, which did not benefit the legitimacy of more radical and transformative solutions.

\subsection{Systemic barriers analysis}

We have identified several mutually reinforcing barriers in the overall MIS that relate to the system functions market formation and destabilization, entrepreneurial activities, and solution-directionality (see Figure 3). The main barrier is the fact that shippers have no attractive business case to adopt, particularly for the more radical sustainable innovations, because (1) there is too little policy support for market formation (-SF5), (2) freight forwarders are not willing to pay a premium for sustainable transportation (-SF5), (3) shippers are waiting for an alternative energy carrier to become dominant and for infrastructure to emerge (-SF4B), and (4) the charterer pays the fuel, thus taking away the incentive for shippers to adopt certain solutions (-SF5). This lack of a business case impairs technology suppliers from investing in developing their technological solutions to a level that is competitive enough for commercialization (-SF1; 2). In combination with the abundant early-stage R\&D funding, this has resulted in a large set of uncompetitive radical solutions that require substantial physical infrastructure development. This systemic barrier reflects low solution-directionality and results in the aforementioned wait-and-see approach of shippers (-SF4B), closing a vicious cycle of systemic barriers in which a lack of demand maintains a lack of supply and vice versa.

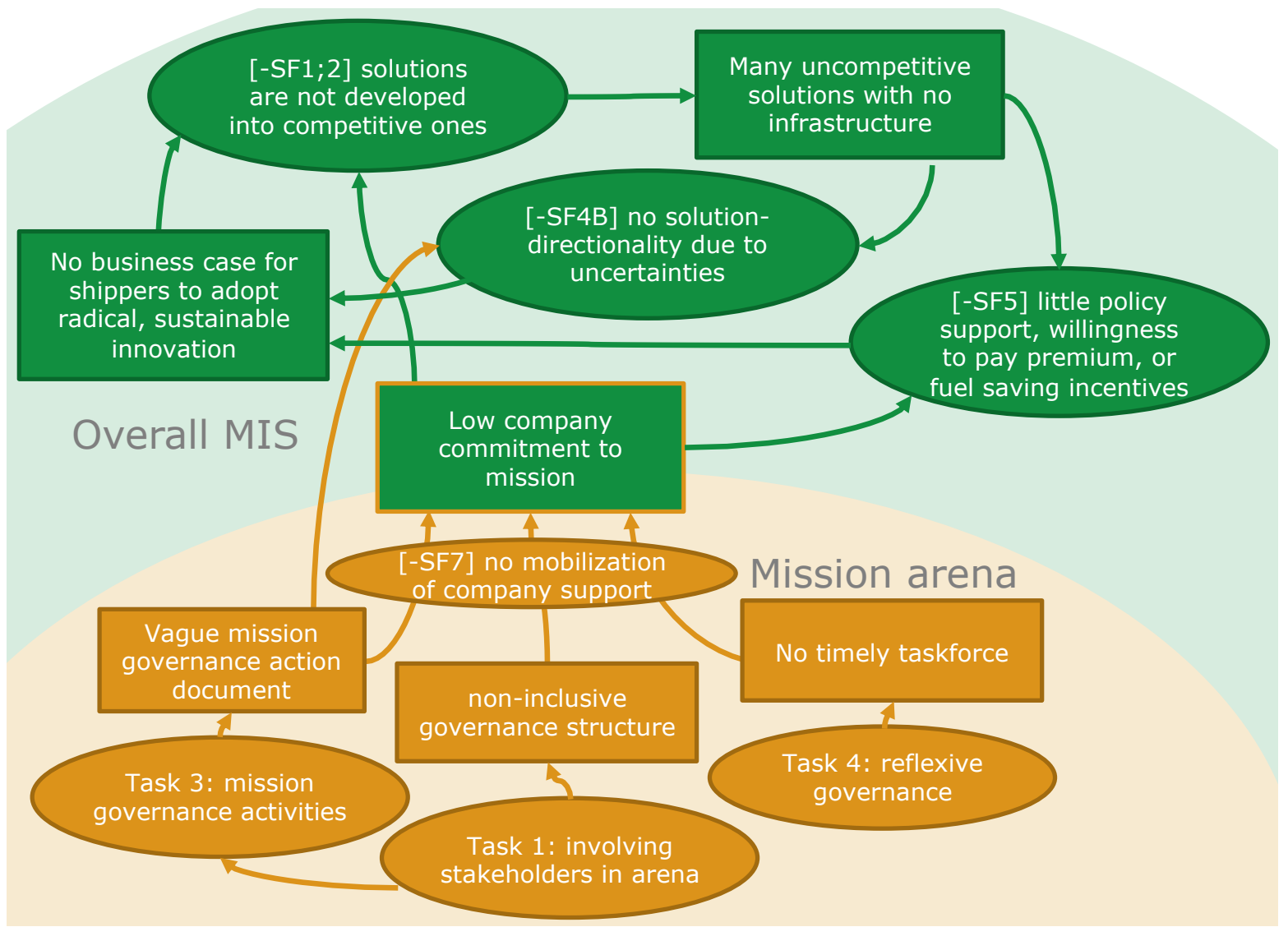

Figure 3: Weak system functions (ovals) and interrelated systemic barriers (rectangles) in the mission arena and overall MIS

\subsection{Contrasting mission governance actions and MIS barriers}


In Section 4.2.1, we indicated four tasks of the mission arena, namely (1) involving stakeholders in the arena, (2) formulating a mission goal, (3) committing to mission governance actions to mobilize the overall MIS, and (4) engaging in reflexive governance. We now reflect, for the case at hand, on how these tasks relate to the previously identified systemic barriers.

On the negative side, the mission arena (task 1 ) hardly involved any individual companies thus missing out on the opportunity to mobilize their support directly. Instead, negotiations on mission formulation and governance actions took place with industry associations. These actors are known to be more defensive towards transitions than their members (Hillman \& Hitt, 1999; Wesseling et al., 2014). As a result of the dominant position of industry associations in the arena, the governance actions that they committed to were limited to 'requesting', 'stimulating' and 'urging' their members to engage in various sustainable shipping activities and lobbying for a worldwide fuel levy (Green Deal, 2019, pp. 14,15 , and 17). Some interviewees perceived these actions as unclear and noncommittal. Involving individual companies may be a more complex and time-consuming negotiation process, but it may eventually result in more industry commitment and hence a more effective mix of mission governance actions. Interviewees also indicated that a quick follow-up to the mission agreement via the promised monitoring and evaluation taskforce (task 4) would also have benefited the mobilization of company commitment.

On the positive side, the mission arena members committed to a total of 64 mission governance actions to support sustainable maritime transport (Green Deal, 2019). While industry commitments were considered to have little impact, some government actions were considered to be more effective. The overview in Table 5 shows that particularly the main barrier of a missing business case is extensively addressed by a broad mix of governance actions, both from a market-forming nature and from a solution-directing perspective. These actions should aspire not only to increase the attractiveness of clean shipping solutions (SF5), but also to provide clarity on preferential solutions (SF4b). Other than concluding that many planned actions target this major barrier, it is still too early to assess their impact.

The aforementioned actions will also affect the related barrier of 'many uncompetitive solutions with no infrastructure', as an improved business case directly translates into more competitive solutions, particularly after learning processes and scale economies kick in. This is likely to trigger a process of demand-driven selection (SF4b) and infrastructure investments (SF6), to which the public side of the mission arena has also pledged its support (SF7).

Table 5: Overview of MIS barriers and corresponding mission governance actions to which actors in the mission arena are committed

\begin{tabular}{|l|l|}
\hline MIS barriers & Mission arena's supportive mission governance actions \\
\hline Missing business case, & Governmental action: \\
due to lack of market & - Plan fiscal incentives and tax relief for electric shipping \\
formation & - Triple Helix develops a profitable business case for zero emission \\
& shipping, supported by research projects and subsidies \\
& - Public procurement criteria will better incorporate sustainability \\
& - Development of a 'sustainable shipping' marketing strategy, including \\
& a sticker to enable transferring its surcharge to the end consumer \\
& - Public procurement of three hybrid-electric, biofueled ships \\
& - Operate public fleets on a 30\% biofuels blend \\
& - Explore other financial support schemes (e.g., guarantees and fiscal \\
& schemes) \\
\hline
\end{tabular}




\begin{tabular}{|c|c|}
\hline & $\begin{array}{l}\text { - Lobby for international sustainable shipping regulations, such as a } \\
\mathrm{CO}_{2} \text { tax and European low emission zones, to maintain a level } \\
\text { economic playing field } \\
\text { Non-governmental action: } \\
\text { - Urge members along the value chain to adopt sustainability as a } \\
\text { purchasing criterium } \\
\text { - Lobby for a global fuel levy } \\
\text { - Push for prestigious awards to include sustainability as a criterion }\end{array}$ \\
\hline $\begin{array}{l}\text { Missing business case, } \\
\text { due to lack of solution- } \\
\text { directionality }\end{array}$ & $\begin{array}{l}\text { Governmental action: } \\
\text { - Provide a regularly updated overview and independent assessment of } \\
\text { available sustainable shipping solutions to enable informed decision } \\
\text { making by shippers and financers } \\
\text { Non-governmental action: } \\
\text { - Urge members to share information on innovative solutions }\end{array}$ \\
\hline $\begin{array}{l}\text { Low company } \\
\text { commitment }\end{array}$ & $\begin{array}{l}\text { Governmental action: } \\
\text { - Allocate } € 5 \text { million of public funding to the Dutch Green Deal } \\
\text { - Explore further R\&D subsidy schemes } \\
\text { - Taskforce to coordinate and implement the Green Deal within } 4 \\
\text { months, and to evaluate its effect } 2.5 \text { years after signing }\end{array}$ \\
\hline
\end{tabular}

\section{Discussion}

Below we reflect on the first approach to studying MIS that we developed and applied in this paper. This approach is prone to changes as the MIS perspective may develop over time through successive conceptual and empirical works, which will highlight different aspects of the MIS. We also provide some suggestions for further research.

First, the conceptual and empirical work undertaken in this paper helps us to elucidate the nature of an MIS. We find that MISs are temporary; that they are embedded in existing innovation system structures that a temporary governance body or mission arena aims to reconfigure, mobilize and direct via different governance actions, towards achieving the mission; and that they inherently involve processes of contestation and coordination. We address these qualities in our MIS definition and via the conceptualization of a mission arena where proponents and opponents of swift transformative action may influence the mission's direction, level of ambition and course of mission governance action. Further research should be done into the mission arena's tasks and how different mission governance structures affect them.

Second, missions are an interface of societal problems and innovative solutions, and as such they greatly increase the complexity of a structural-functional analysis, compared to that of a conventional TIS. As a consequence, to maintain overview and feasibility, some aspects may lose their level of detail. ${ }^{11}$ In this paper, we did not conduct a longitudinal analysis, nor did we study clusters of solutions separately in the context of the broader MIS. Depending on the research aim, this may in some cases be desirable, however - for example when analyzing the embeddedness of a TIS in a broader MIS context or when systematically exploring different types of solution-interactions. Central to technology-specificity is also the theme of intended and unintended solution-directionality (see Azar \& Sandén, 2011). As missions are made increasingly actionable, they tend to favor some solutions over others, depending on their technological or social nature, stages of development, and other factors.

\footnotetext{
${ }^{11}$ As is the case for other systems perspectives that are broader in scope than the TIS, like the National Innovation System and Multi-Level Perspective.
} 
Anticipating and assessing such - sometimes unintended - solution dynamics within an MIS, and the way in which the mission arena co-constructs and reflexively deals with these insights, poses an important research direction in the field of reflexive governance (Smith \& Stirling, 2007; Weber \& Rohracher, 2012).

Third, the applicability of the MIS framework should be tested by applying it to different types of missions. The MIP literature states that each mission is unique (Janssen et al., 2020; Larrue, 2021; Mazzucato, 2018), and that missions can differ along different dimensions. These include the following:

- the level of 'wickedness' as degrees of complexity, uncertainty and contestation differ per mission (Alford \& Head, 2017; Wanzenböck et al., 2020)

- the type of solutions, technological or social (Pel et al., 2020b) that the mission focuses on

- the focus on the development and/or diffusion of those solutions ${ }^{12}$

- the number of possible 'solution-pathways', and ensuing complexities, within the mission scope

- the need for system optimization or transformation to accomplish the mission goal (Wanzenböck et al., 2020)

- the 'big science' missions of old or today's challenge-led missions (Kaldewey, 2018; Robinson \& Mazzucato, 2019)

- their geographical scope (local, regional, national, supranational and global) and the ensuing coordination problems (Wanzenböck \& Frenken, 2020)

- their bottom-up or top-down definition and governance structures (Janssen et al., 2021) and their outside-managerial or inside-political governance strategies (Smith \& Stirling, 2007)

Systematically comparing such missions and the MIS dynamics and challenges that they present would be a fruitful way of theory building on how different missions and mission arenas impact MIS dynamics. Specifically, further research could examine how and to what extent regional, sectoral, national, global and/or technological innovation systems components are mobilized and combined, driven by different types of missions and mission arenas. Furthermore, MIS analyses should be applied to cases that more prominently feature social solutions, to assess if the current MIS framework needs to be further developed to capture all the dynamics of different types of social innovations.

Fourth, we find that the systemic barriers identified via an MIS analysis can be used to

1) explore ex ante which MIS barriers should be targeted by a yet undefined set of mission governance actions

2) tentatively evaluate ex ante whether planned or very recently implemented mission governance actions effectively target these barriers

3) assess ex post the impact that previously implemented mission governance actions have had over time on the development of the MIS

Our case study is an example of the second type of MIS application; although we conclude that the planned mission governance actions effectively target the systemic barriers, their impact (application 3) cannot be assessed until some years after their implementation. One effective way of ex-post impact assessment is to have at least one benchmark structural-functional assessment, so that the resolution of and changes in systemic barriers can be analyzed over time, as an indication of the effectiveness of the mission actions undertaken.

\footnotetext{
${ }^{12}$ For example, European missions have a strong focus on development whereas the Dutch Regional Energy Strategies focus almost exclusively on diffusion (Schwenke \& Schuurs, 2017).
} 


\section{Conclusions}

In this paper we developed a first approach to studying MIS, and we illustrated its applicability to the Dutch mission of sustainable short sea shipping. Building on the structural-functional approach, we identified the most important systemic barriers that inhibit the mission from being pursued more effectively. We subsequently determined if the governance actions supporting the mission are targeted at these barriers, to assess the actions' effectiveness.

We conclude that the MIS barriers we identified are indeed targeted by a wide array of mission governance actions, by particularly public organizations. However, we also find that individual firms were not adequately involved in the mission arena, which instead engaged with industry associations that negotiated vague and non-committal governance actions on their part. Overall, this, and not directly following the initial mission action up with a taskforce, did not do much to overcome the barrier of a lack of company support to the mission. There also was more potential to provide the much-needed solution-directionality in a MIS characterized by a wide range of still uncompetitive solutions amongst which different types of actors need to select.

\section{References}

Alford, J., Head, B., 2017. Wicked and less wicked problems : A typology and a contingency framework. Policy Soc. https://doi.org/10.1080/14494035.2017.1361634

Alford, J., Head, B., 2015. Wicked and less wicked problems : A typology and a contingency framework. Panel T04P06 - Policy responses to 'wicked Probl. - theory Pract. Int. Conf. Public Policy 4035, 1-26. https://doi.org/10.1080/14494035.2017.1361634

Anink, D., Sakko, S., 2019. EFSA Roadmap 2050.

Azar, C., Sandén, B.A., 2011. The elusive quest for technology-neutral policies. Environ. Innov. Soc. Transitions 1, 135-139. https://doi.org/10.1016/j.eist.2011.03.003

Baresic, D., Smith, T., Raucci, K., Rehmatulla, C., Narula, N., Rojon, I., 2018. LNG as a marine fuel in the EU: Market, bunkering infrastructure investments and risks in the context of GHG reductions. London.

Bergek, A., Hekkert, M., Jacobsson, S., Markard, J., Sandén, B., Truffer, B., 2015. Technological innovation systems in contexts: Conceptualizing contextual structures and interaction dynamics. Environ. Innov. Soc. Transitions. https://doi.org/10.1016/j.eist.2015.07.003

Bergek, A., Jacobsson, S., Carlsson, B., Lindmark, S., Rickne, A., 2008. Analyzing the functional dynamics of technological innovation systems: A scheme of analysis. Res. Policy 37, 407-429. https://doi.org/10.1016/j.respol.2007.12.003

Bickerstaff, K., Walker, G., 2005. Shared visions, unholy alliances: Power, governance and deliberative processes in local transport planning. Urban Stud. 42, 2123-2144. https://doi.org/10.1080/00420980500332098

Carlsson, B., Stankiewicz, R., 1991. On the nature, function and composition of technological systems. J. Evol. Econ. 93-118.

Christoff, P., 2006. Post-Kyoto? Post-Bush? Towards an effective 'climate coalition of the willing.' Int. Aff. 82, 831-860. https://doi.org/10.1111/j.1468-2346.2006.00574.x

David, M., 2017. Moving beyond the heuristic of creative destruction: Targeting exnovation with policy mixes for energy transitions. Energy Res. Soc. Sci. 33, 138-146.

https://doi.org/10.1016/j.erss.2017.09.023

DG MOVE, 2015. State of the Art on Alternative Fuels Transport Systems in the European Union. https://doi.org/10.1099/jmm.0.47106-0

Diercks, G., Larsen, H., Steward, F., 2019. Transformative innovation policy: Addressing variety in an emerging policy paradigm. Res. Policy 48, 880-894.

https://doi.org/10.1016/j.respol.2018.10.028 
DNV GL, 2019. Comparison of Alternative Marine Fuels.

EC, 2017. Guidance/Best practices document on monitoring and reporting of fuel consumption, $\mathrm{CO} 2$ emissions and other relevant parameters pursuant to Regulation 2015/757 on monitoring, reporting and verification emissions from maritime transport.

Edquist, C., 2004. Systems of Innovation: perspectives and challenges. Fagerberg/The Oxford Handb. Innov.

Edquist, C., Lundvall, B.A., 1993. Comparing the Danish and Swedish systems of innovation, in: Nelson, R. (Ed.), National Innovation Systems. Oxford University Press, New York.

Environment, T.\&, 2018. CNG and LNG for vehicles and ships - the facts.

Fink, H., 1996. Arenabegreber - mellem ørkensand \& ørkensand, in: Fink, H. (Ed.), Arenaer - Om Politik \& Inscenesættelse. Aarhus Universitetsforlag, Aarhus, pp. 7-22.

Fogelberg, H., Sandén, B., 2008. Understanding reflexive systems of innovation: An analysis of Swedish nanotechnology discourse and organization. Technol. Anal. Strateg. Manag. 20, 65-81. https://doi.org/10.1080/09537320701726593

Foray, D., Mowery, D.C., Nelson, R.R., 2012. Public R\&D and social challenges: What lessons from mission R\&D programs? Res. Policy 41, 1697-1702. https://doi.org/10.1016/j.respol.2012.07.011

Frenken, K., 2017. A Complexity-Theoretic Perspective on Innovation Policy. Complexity, Gov. Networks 0, 35-47. https://doi.org/http://dx.doi.org/10.20377/cgn-41

Geels, F.W., 2004. From sectoral systems of innovation to socio-technical systems: Insights about dynamics and change from sociology and institutional theory. Res. Policy 33, 897-920. https://doi.org/10.1016/j.respol.2004.01.015

Geertsma, C. (E) dr. ir., Krijgsman, ir. M., 2019. Alternative fuels and power systems to reduce environmental impact of support vessels. Proc. Mar. Electr. Control Syst. Saf. Conf. 1, 1-9. https://doi.org/10.24868/issn.2515-8198.2019.003

Ghazinoory, S., Nasri, S., Ameri, F., Montazer, G.A., Shayan, A., 2020. Why do we need 'Problemoriented Innovation System (PIS)' for solving macro-level societal problems? Technol. Forecast. Soc. Change 150. https://doi.org/10.1016/j.techfore.2019.119749

Green Deal, 2019. Green Deal on Maritime and Inland Shipping and Ports.

Grillitsch, M., Hansen, T., Coenen, L., Miörner, J., Moodysson, J., 2019. Innovation policy for systemwide transformation : The case of strategic innovation programmes ( SIPs ) in Sweden. Res. Policy 48, 1048-1061. https://doi.org/10.1016/j.respol.2018.10.004

Haddad, C., Nakić, V., Bergek, A., Hellsmark, H., 2019. The policymaking process of transformative innovation policy: a systematic review. 4th Int. Conf. Public Policy 1-45.

Haddad, C.R., Bergek, A., 2020. A functions approach for evaluating transformative innovation policy. IST conference.

Harrabin, R., 2019. \$5bn fund unveiled for climate-friendly shipping. BBC.

Hekkert, M.P., Janssen, M.J., Wesseling, J.H., Negro, S.O., 2020. Mission-oriented innovation systems. Environ. Innov. Soc. Transitions 34, 76-79.

Hekkert, M.P., Suurs, R.A.A., Negro, S.O., Kuhlmann, S., Smits, R.E.H.M., 2007. Functions of innovation systems: A new approach for analysing technological change. Technol. Forecast. Soc. Change 74, 413-432. https://doi.org/10.1016/j.techfore.2006.03.002

Hennigs, N., Schmidt, S., Wiedmann, K.P., Karampournioti, E., Labenz, F., 2017. Measuring brand performance in the cruise industry: Brand experiences and sustainability orientation as basis for value creation. Int. J. Serv. Technol. Manag. 23, 189-203.

https://doi.org/10.1504/IJSTM.2017.085473

Henningsgård, S., 2019. Someone has to go first [WWW Document]. Marit. Impact. URL https://www.dnvgl.com/expert-story/maritime-impact/Someone-has-to-go-first.html

Hillman, a J., Hitt, M. a, 1999. Corporate Political Strategy Formulation: A Model of Approach, Participation and Strategic Decisions. Acad. Manag. Rev. 24, 825-842.

Howlett, M., Rayner, J., 2013. Patching vs Packaging in Policy Formulation: Complementary Effects, 
Goodness of Fit, Degrees of Freedom, and Feasibility in Policy Portfolio Design. Polit. Gov. 1, 170-182. https://doi.org/10.12924/pag2013.01020170

Howlett, M., Rayner, J., 2007. Design Principles for Policy Mixes: Cohesion and Coherence in 'New Governance Arrangements.' Policy Soc. 26, 1-18. https://doi.org/10.1016/S1449-

4035(07)70118-2

I\&W, 2019. Duurzame mobiliteit.

IGU, 2020. 2020 World LNG Report, International Gas Union (IGU.

IMO, 2020a. Reducing greenhouse gas emissions from ships.

IMO, 2020b. Sulphur oxides (SOx) and Particulate Matter (PM) - Regulation 14 [WWW Document].

URL

http://www.imo.org/en/OurWork/Environment/PollutionPrevention/AirPollution/Pages/Sulph ur-oxides-(SOx)---Regulation-14.aspx (accessed 9.16.20).

IPCC, 2018. Chapter 2: Mitigation Pathways Compatible with $1.5^{\circ} \mathrm{C}$ in the Context of Sustainable Development, IPCC special report Global Warming of $1.5^{\circ} \mathrm{C}$.

Isoaho, K., Markard, J., 2020. The Politics of Technology Decline: Discursive Struggles over Coal Phase-Out in the UK. Rev. Policy Res. 37, 342-368. https://doi.org/10.1111/ropr.12370

Janssen, M.J., Torrens, J., Wesseling, J., Patterson, J., 2020. Position paper 'Mission - oriented innovation policy observatory.'

Janssen, M.J., Torrens, J.C.L., Wesseling, J., Wanzenböck, I., Patterson, J., 2021. The promises and premises of mission-oriented innovation policy: A reflection and ways forward. Sci. Public Policy Manuscr.

Jørgensen, U., 2012. Mapping and navigating transitions - The multi-level perspective compared with arenas of development. Res. Policy 41, 996-1010.

https://doi.org/10.1016/j.respol.2012.03.001

Kaldewey, D., 2018. The Grand Challenges Discourse: Transforming Identity Work in Science and Science Policy. Minerva 56, 161-182. https://doi.org/10.1007/s11024-017-9332-2

Kashyap, V., 2019. Understanding Power Management System: How To Reduce Power Consumption On Ships. Mar. Technol.

Kattel, R., Mazzucato, M., 2018. Mission-oriented innovation policy and dynamic capabilities in the public sector 27, 787-801. https://doi.org/10.1093/icc/dty032

Kivimaa, P., Kern, F., 2016. Creative Destruction or Mere Niche Creation? Innovation Policy Mixes for Sustainability Transitions. Res. Policy 45, 205-217.

https://doi.org/10.1016/j.respol.2015.09.008

Krippendorff, K., 2004. Reliability in Content Analysis. Hum. Commun. Res. 30, 411-433. https://doi.org/10.1111/j.1468-2958.2004.tb00738.x

Larrue, P., 2021. The design and implementation of mission-oriented innovation policies: A new systemic policy approach to address societal challenges.

Levin, K., Cashore, B., Bernstein, S., Auld, G., 2012. Overcoming the tragedy of super wicked problems: Constraining our future selves to ameliorate global climate change. Policy Sci. 45, 123-152. https://doi.org/10.1007/s11077-012-9151-0

Loorbach, D., 2010. Transition management for sustainable development: A prescriptive, complexitybased governance framework. Governance 23, 161-183. https://doi.org/10.1111/j.14680491.2009.01471.x

Loorbach, D., Frantzeskaki, N., Avelino, F., 2017. Sustainability Transitions Research: Transforming Science and Practice for Societal Change. Annu. Rev. Environ. Resour. 42, 599-626. https://doi.org/10.1146/annurev-environ-102014-021340

Malerba, F., Orsenigo, L., 1997. Technological Regimes and Sectoral Patterns of Innovative Activities. Ind. Corp. Chang. 6, 83-118. https://doi.org/10.1093/icc/6.1.83

Malerba, F., Orsenigo, L., Breschi, S., 2000. Technological regimes and schumpeterian patterns of innovation. Econ. J. 110, 388-410. https://doi.org/10.1111/1468-0297.00530

Markard, J., Hekkert, M., Jacobsson, S., 2015. The technological innovation systems framework: 
Response to six criticisms. Environ. Innov. Soc. Transitions 16, 76-86.

https://doi.org/10.1016/j.eist.2015.07.006

Mazzucato, M., 2018. Mission-Oriented Research \& Innovation in the European Union. https://doi.org/10.2777/36546

Mazzucato, M., 2017. Mission-Oriented Innovation Policy Challenges and opportunities. UCL Inst. Innov. Public Purp. 1-41.

Pel, B., Haxeltine, A., Avelino, F., Dumitru, A., Kemp, R., Bauler, T., Kunze, I., Dorland, J., Wittmayer, J., Jørgensen, M.S., 2020a. Towards a TSI theory : a relational framework and 12 propositions. Res. Policy 49, 24. https://doi.org/10.1016/j.respol.2020.104080

Pel, B., Wittmayer, J., Dorland, J., Søgaard Jørgensen, M., 2020b. Unpacking the social innovation ecosystem: an empirically grounded typology of empowering network constellations. Innov. Eur. J. ofSocial Sci. Res. https://doi.org/10.1080/13511610.2019.1705147

Port of Rotterdam, 2019. Haalbaarheid methanol als transportbrandstof in maritieme sector [WWW Document].

Regeerakkoord, 2017. Vertrouwen in de toekomst.

Rehfeld, D., Terstriep, J., Welschhoff, J., Alijani, S., 2015. Comparative Report on Social Innovation Framework. Proy. SIMPACT.

Rijkswaterstaat, 2020. Vlootvervanging [WWW Document]. URL https://www.rijkswaterstaat.nl/water/waterbeheer/beheer-en-ontwikkelingrijkswateren/rijksrederij/vlootvervanging.aspx

Robinson, D.K.R., Mazzucato, M., 2019. The evolution of mission-oriented policies: Exploring changing market creating policies in the US and European space sector. Res. Policy 48, 936948. https://doi.org/10.1016/j.respol.2018.10.005

Rosenbloom, D., 2018. Framing low-carbon pathways: A discursive analysis of contending storylines surrounding the phase-out of coal-fired power in Ontario. Environ. Innov. Soc. Transitions 27, 129-145. https://doi.org/10.1016/j.eist.2017.11.003

Safety4Sea, 2019. Number of ships using LNG, scrubbers to increase from 2020.

Sandén, B. a., Hillman, K.M., 2011. A framework for analysis of multi-mode interaction among technologies with examples from the history of alternative transport fuels in Sweden. Res. Policy 40, 403-414. https://doi.org/10.1016/j.respol.2010.12.005

Schlaile, M.P., Urmetzer, S., Blok, V., Andersen, A.D., Timmermans, J., Mueller, M., Fagerberg, J., Pyka, A., 2017. Innovation systems for transformations towards sustainability? Taking the normative dimension seriously. Sustain. 9. https://doi.org/10.3390/su9122253

Schot, J., Steinmueller, W.E., 2018. Three frames for innovation policy : R \& D , systems of innovation and transformative change. Res. Policy 47, 1554-1567.

https://doi.org/10.1016/j.respol.2018.08.011

Schwenke, A., Schuurs, R., 2017. Slim schakele, Lessen voor een regionale energiestrategie.

Scott, W.R., 2014. Institutions and organizations: ideas, interests, and identities. Sage, Los Angeles.

Smith, A., Stirling, A., 2007. Moving Outside or Inside? Objectification and Reflexivity in the Governance of Socio-Technical Systems. J. Environ. Policy Plan. 9, 351-373. https://doi.org/10.1080/15239080701622873

Smits, P., 2020. Startups in de scheepvaart, het blijft vaak vallen en opstaan [WWW Document].

Smits, R., Kuhlmann, S., 2004. The rise of systemic instruments in innovation policy. Int. J. Foresight Innov. Policy 1, 4. https://doi.org/10.1504/IJFIP.2004.004621

Stirling, A., 2008. "Opening Up" and "Closing Down": Power, Participation, and Pluralism in the Social Appraisal of Technology. Sci. Technol. Hum. Values 33, 262-294.

Suurs, R. a a, Hekkert, M.P., 2009. Competition between first and second generation technologies: Lessons from the formation of a biofuels innovation system in the Netherlands. Energy 34, 669-679. https://doi.org/10.1016/j.energy.2008.09.002

Suurs, R.A.A., 2009. Motors of sustainable innovation: Towards a theory on the dynamics of technological innovation systems. Utrecht University. 
Terstriep, J., Rehfeld, D., Kleverbeck, M., 2020. Favourable social innovation ecosystem(s)? - An explorative approach. Eur. Plan. Stud. 28, 881-905.

https://doi.org/10.1080/09654313.2019.1708868

Topsector Energie, 2020. Project overzicht [WWW Document].

Turnheim, B., Geels, F.W., 2012. Regime destabilisation as the flipside of energy transitions: Lessons from the history of the British coal industry (1913-1997). Energy Policy 50, 35-49. https://doi.org/10.1016/j.enpol.2012.04.060

van Nieuwenhuizen, C., 2019. Kamerbrief bij Green Deal Zeevaart, Binnenvaart en Havens.

Voss, J.P., Kemp, R., 2006. Sustainability and reflexive governance: an introduction, in: Voss, J.P., Bauknecht, D., Kemp, R. (Eds.), Reflexive Governance for Sustainable Development. Edward Elgar, Cheltenham, pp. 419-437.

Wanzenböck, I., Frenken, K., 2020. The subsidiarity principle in innovation policy for societal challenges. Glob. Transitions 2, 51-59. https://doi.org/10.1016/j.glt.2020.02.002

Wanzenböck, I., Wesseling, J.H., Frenken, K., Hekkert, M.P., Weber, K.M., 2020. A framework for mission-oriented innovation policy: Alternative pathways through the problem-solution space. Sci. Public Policy 1-16. https://doi.org/10.1093/scipol/scaa027

Wärtsilä Corporation, 2020. Wärtsilä customised LNG solution chosen for four next-generation short-sea cargo vessels.

Weber, K.M., Rohracher, H., 2012. Legitimizing research, technology and innovation policies for transformative change: Combining insights from innovation systems and multi-level perspective in a comprehensive "failures" framework. Res. Policy 41, 1037-1047. https://doi.org/10.1016/j.respol.2011.10.015

Wesseling, J.H., Edquist, C., 2018. Public procurement for innovation to help meet societal challenges : a review and case study. Sci. Public Policy 45, 493-502. https://doi.org/10.1093/scipol/scy013

Wesseling, J.H., Farla, J.C.M., Sperling, D., Hekkert, M.P., 2014. Car manufacturers' changing political strategies on the ZEV mandate. Transp. Res. Part D-Transport Environ. 33, 196-209. https://doi.org/10.1016/j.trd.2014.06.006

Wesseling, J.H., Larue, P., Janssen, M.J., Wanzenböck, I., Penna, C.R., Goetheer, A., 2020. MissionOriented Innovation Policy workshop series : Observations from workshop 1-Scoping an Agenda setting 1-10.

Wesseling, J.H., Van der Vooren, A., 2017. Lock-in of mature innovation systems: The transformation toward clean concrete in the Netherlands. J. Clean. Prod. 155, 114-124. https://doi.org/10.1016/j.jclepro.2016.08.115

Wieczorek, A. J., Hekkert, M.P., 2012. Systemic instruments for systemic innovation problems: A framework for policy makers and innovation scholars. Sci. Public Policy 39, 74-87. https://doi.org/10.1093/scipol/scr008

Wieczorek, Anna J, Hekkert, M.P., 2012. Systemic instruments for systemic innovation problems: A framework for policy makers and innovation scholars. Sci. Public Policy 39, 74-87.

Wittmann, F., Hufnagl, M., Edler, J., 2019. Scientific support for the Hightech-Forum of the German Hightech-Strategy ( WP6 ): Developing a Typology for Mission- Oriented Innovation Policies 42. 


\section{Appendix I}

Table A.I: Overview of solutions, their TRL, innovation type, involvement of interviewees, advantages, and disadvantages. Based on interview data and a review of grey literature, such as trade magazines and technology reports, and of peer reviewed studies; of particular note are the reviews by DG MOVE (2015), DNV GL

\begin{tabular}{|c|c|c|c|c|}
\hline Solutions & TRL & Innovation type & Advantages & Disadvantages \\
\hline \multicolumn{5}{|c|}{ Technological solutions to the ship } \\
\hline $\begin{array}{l}\text { Exhaust gas treatment } \\
\text { systems (scrubbers) }\end{array}$ & 9 & $\begin{array}{l}\text { Incremental: end-of-pipe solution to } \\
\text { fossil-fuel-based drive train }\end{array}$ & $\begin{array}{l}\text { Short-term emission reduction in SOx, NOx } \\
\text { and particulate matter }\end{array}$ & $\begin{array}{l}\text { Still applied to diesel and heavy fuel oil; some } \\
\text { systems 'move the problem' by pumping } \\
\text { emissions into the water }\end{array}$ \\
\hline $\begin{array}{l}\text { Electric propulsion } \\
\text { systems }\end{array}$ & $5-9$ & Radical: replacing drive train & $\begin{array}{l}\text { Zero emission depending on energy source; } \\
\text { diesel-generated systems have comparatively } \\
\text { low CAPEX \& OPEX; ability to use diesel- } \\
\text { fuelled generator now and replace later }\end{array}$ & $\begin{array}{l}\text { Currently applied to diesel and LNG and } \\
\text { therefore not yet zero emission. }\end{array}$ \\
\hline $\begin{array}{l}\text { Electrical sensor } \\
\text { systems }\end{array}$ & 9 & $\begin{array}{l}\text { Incremental: add-on to make } \\
\text { existing operations more efficient }\end{array}$ & $\begin{array}{l}\text { Achieves higher efficiency via lower ship } \\
\text { resistance; applicable to all energy carriers }\end{array}$ & None mentioned or found \\
\hline $\begin{array}{l}\text { Efficiency gains within } \\
\text { established } \\
\text { technologies }\end{array}$ & 9 & $\begin{array}{l}\text { Incremental: improvements to } \\
\text { hydrodynamics, or more efficient or } \\
\text { 'low revolutions per minute' } \\
\text { propulsion systems }\end{array}$ & $\begin{array}{l}\text { Some solutions applicable to all energy } \\
\text { carriers }\end{array}$ & $\begin{array}{l}\text { Hydrodynamics improvements of ships may } \\
\text { approach physical boundaries; some solutions } \\
\text { specific to fossil fuel drive train }\end{array}$ \\
\hline \multicolumn{5}{|c|}{ Alternative energy carriers } \\
\hline Ammonia & $9 / 5$ & $\begin{array}{l}\text { Incremental: when used in an } \\
\text { internal combustion engine, } \\
\text { requiring a catalyst to crack } \\
\text { ammonia / Radical: when used } \\
\text { directly in a fuel cell }\end{array}$ & $\begin{array}{l}\text { Zero carbon emissions, already produced on } \\
\text { large scale }\end{array}$ & $\begin{array}{l}\text { Still immature and uncompetitive, less than half } \\
\text { the energy density of diesel, relatively high } \\
\text { CAPEX/MWh, OPEX higher than other } \\
\text { alternatives; requires infra changes }\end{array}$ \\
\hline Batteries & 9 & $\begin{array}{l}\text { Incremental: when minor battery is } \\
\text { used for peak shaving / Radical: } \\
\text { when the ship is fully electric }\end{array}$ & $\begin{array}{l}\text { Zero emission when full electric; can be used } \\
\text { for peak shaving in hybrid systems }\end{array}$ & $\begin{array}{l}\text { Very low energy density and limited range - } \\
\text { reducing applicability to short-distance shipping; } \\
\text { still uncompetitive - very high CAPEX/MWh; } \\
\text { requires infra changes }\end{array}$ \\
\hline Biofuels & $5-9$ & $\begin{array}{l}\text { Incremental: biofuels require no or } \\
\text { some adaptation to the internal } \\
\text { combustion engine }\end{array}$ & $\begin{array}{l}\text { Limited innovation effort, including infra } \\
\text { changes; potential for zero net emission; } \\
\text { gradual diffusion possible via blending }\end{array}$ & $\begin{array}{l}\text { No zero exhaust emissions, competition with } \\
\text { other crops; still uncompetitive; onboard storage } \\
\text { stability and corrosion issues }\end{array}$ \\
\hline Hydrogen & 9 & $\begin{array}{l}\text { Radical: when used with a fuel cell, it } \\
\text { replaces the entire drive train }\end{array}$ & Zero emission & $\begin{array}{l}\text { Still immature and uncompetitive - very high } \\
\text { CAPEX \& OPEX; short range or requires much } \\
\text { storage space; requires infra changes }\end{array}$ \\
\hline
\end{tabular}




\begin{tabular}{|c|c|c|c|c|}
\hline LNG (liquid natural gas) & 9 & $\begin{array}{l}\text { Incremental: is used in an internal } \\
\text { combustion engine }\end{array}$ & $\begin{array}{l}\text { Better air quality than diesel and heavy oil; } \\
\text { competitive fuel costs; infra already in place }\end{array}$ & $\begin{array}{l}\text { Still emissions; methane slip; storage is } \\
\text { expensive }\end{array}$ \\
\hline Methanol & 7 & $\begin{array}{l}\text { Incremental: is used in an internal } \\
\text { combustion engine }\end{array}$ & $\begin{array}{l}\text { Better air quality than diesel and heavy oil; } \\
\text { comparatively easy and cheap to store, low } \\
\text { CAPEX/MWh }\end{array}$ & $\begin{array}{l}\text { Still emissions; not a direct replacement for } \\
\text { diesel; lower energy density than diesel; high to } \\
\text { very high CAPEX \& OPEX when used with fuel } \\
\text { cell; requires infra changes }\end{array}$ \\
\hline \multicolumn{5}{|l|}{ Social solutions } \\
\hline $\begin{array}{l}\text { Efficient shipping } \\
\text { routes and speeds }\end{array}$ & 9 & $\begin{array}{l}\text { Incremental: add-on sensors and } \mathrm{Al} \\
\text { tools to determine the most efficient } \\
\text { route and speed; organizational and } \\
\text { business model changes }\end{array}$ & Competitive, add-on solution to any ship & $\begin{array}{l}\text { Not always in line with current business models } \\
\text { aimed at speed and timing }\end{array}$ \\
\hline $\begin{array}{l}\text { Smarter global } \\
\text { production and } \\
\text { transportation system }\end{array}$ & $\mathrm{N} / \mathrm{A}$ & $\begin{array}{l}\text { No innovation, but requires a } \\
\text { profound geographical and } \\
\text { organizational shift in production } \\
\text { and transportation systems }\end{array}$ & Lowers need for transportation & $\begin{array}{l}\text { Substantial macro-economic organizational } \\
\text { barriers }\end{array}$ \\
\hline
\end{tabular}

